\title{
SAMPAH PLASTIK DI PERAIRAN PESISIR DAN LAUT : IMPLIKASI KEPADA EKOSISTEM PESISIR DKI JAKARTA
}

\author{
MARINE PLASTICS DEBRIS : \\ IMPLICATION TO THE COASTAL ECOSYSTEM IN DKI JAKARTA
}

Devi Dwiyanti Suryono

Pusat Riset Kelautan

Badan Riset Kelautan dan Perikanan, Kementerian Kelautan dan Perikanan

e-mail : devibasworo@yahoo.com

Diterima: 14 Juni 2019 ; Perbaikan: 02 Juli 2019 ; Disetujui: 15 Agustus 2019

\begin{abstract}
ABSTRAK
Sampah plastik merupakan ancaman bagi keberlanjutan sumber daya alam hayati saat ini. Berbagai upaya telah dilakukan oleh Pemerintah daerah baik pusat dan daerah dalam mengelola sampah ini. Salah satunya adalah Pemerinntah Provinsi DKI Jakarta yang memiliki cakupan wilayah dari darat hingga Perairan kepulauan Seribu. Sampah plastik dapat berimplikasi terhadap ekosistem di pesisir DKI Jakarta, salah satunya adalah menutup tunas-tunas mangrove saat air surut, sehingga apabila berlanjut dapat menghambat pertumbuhan mangrove.
\end{abstract}

Kata kunci: Sampah plastik, pesisir dan laut, ekosistem pesisir, DKI Jakarta.

\section{ABSTRACT}

Plastic garbage is a threat to the sustainability of natural resources nowadays. Massive efforts have been applied by central and provincial governments in order to managing this garbage problematics. One of them is the Jakarta Provincial Government, which has a regional territorial from the terrestrial until thousand islands coastal waters. Plastic garbage can have impact to the coastal ecosystem of Jakarta. One of them is closing up mangrove shoots right as the ebb tidal waters is receding, when the plastic stays longer in the mangrove area, it will reduce the growth rate of mangrove trees.

Keywords: plastic garbage, coastal and marine, coastal ecosystem, jakarta.

\section{PENDAHULUAN}

Plastik adalah istilah umum bagi polimer, yaitu material yang terdiri dari rantai panjang karbon dan elemen lain, seperti oksigen, nitrogen, klorin atau belerang yang mudah dibuat menjadi berbagai bentuk dan ukuran. Plastik dibuat dengan cara polimerisasi yaitu menyusun dan membentuk bahanbahan dasar plastik (monomer) secara sambungmenyambung (Setyablogku, 2012). Plastik juga mengandung zat nonplastik yang disebut aditif. Zat aditif diperlukan untuk memperbaiki sifat plastik itu sendiri. Bahan aditif untuk plastik diantaranya berfungsi sebagai pewarna, antioksidan, penyerap sinar ultraviolet dan antilekat (Setyablogku, 2012). Plastik merupakan sebuah bahan yang mudah dibentuk menjadi berbagai jenis material. Plastik dibentuk dari ikatan polimer organik maupun anorganik, seperti karbon, silikon, hidrogen, oksigen dan klorida (Shah et al., 2008). Keunggulan plastik adalah sifatnya yang kuat, anti korosi dan persisten. Selain itu, plastik termasuk material yang ekonomis sehingga banyak digunakan untuk berbagai aktivitas manusia (Gambar 1). Terdapat 5 (lima) jenis utama plastik yang paling banyak digunakan dan diproduksi secara massal, yaitu polyethylene terephthalate (PET), high-density polyethylene (HDPE), polyvinyl chloride (PVC), lowdensity polyethylene (LDPE), dan polypropylene (PP) (Association of European Plastics Manufacturers, 2011).

Penggunaan plastik dalam kehidupan sehari-hari mengalami peningkatan karena sifat keunggulannya tersebut. Menurut Kemenperin (2013), sekitar 1,9 juta ton plastik diproduksi selama tahun 2013 di Indonesia dengan rata-rata produksi 1,65 juta ton/tahun. 


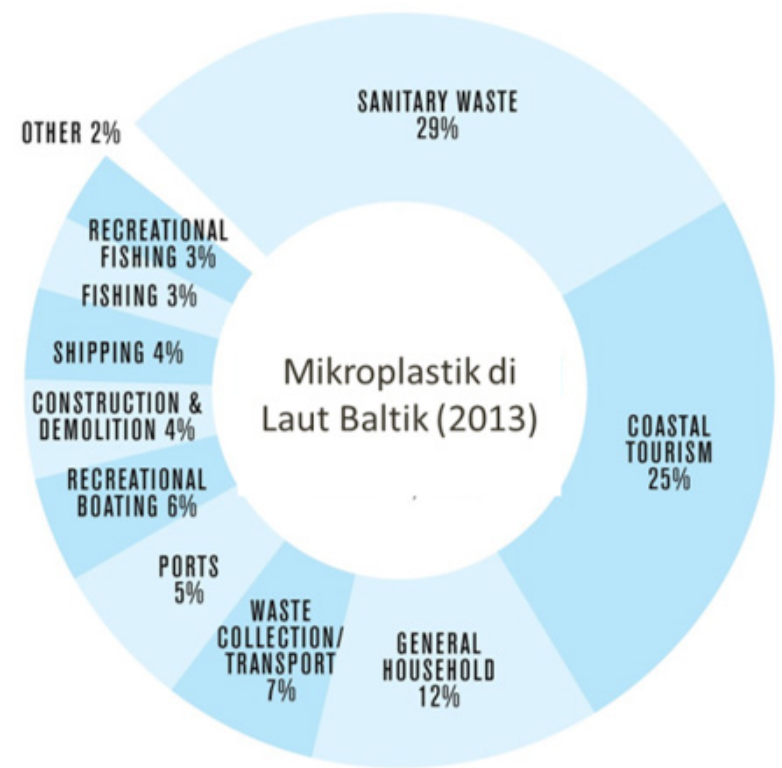

Gambar 1. Sumber Plastik di Laut Baltik, Eropa (Sumber: Arcadis, 2013)

Jumlah konsumsi plastik berpengaruh signifikan terhadap sampah plastik yang dihasilkan. Kota Jakarta misalnya, dengan penduduk sebanyak 9 juta jiwa, dan jumlah sampah per hari sekitar 5000 ton maka jumlah plastik yang ditimbun mencapai 400 ton. Dari jenis tersebut sampah plastik yang ditemui umumnya berjenis PP (Sahwan et al., 2005). Thompson (2006) in Cauwenberghe et al. (2013) memperkirakan bahwa $10 \%$ dari semua plastik yang baru diproduksi akan dibuang melalui sungai dan berakhir di laut. Hal ini berarti sekitar 165 ribu ton plastik/tahun akan bermuara di perairan laut Indonesia.

Saat ini, plastik merupakan bagian terbesar dari sampah di lautan di seluruh dunia. Dengan berat jenisnya yang khas, plastik merupakan penyusun sampah di lautan hingga $90 \%$ dari total sampah secara keseluruhan, dengan rincian: pantai $(32-90 \%)$, air muka laut (86\%), dan dasar laut (47-85\%). Plastik ditemukan di garis pantai, mengapung di permukaan laut dan samudera, melayang dalam kolom air serta menjadi limbah yang mendiami dasar lautan. Laju peningkatan jumlah limbah plastik pada lingkungan perairan sekitar 100.000 partikel per $\mathrm{m}^{2}$ pada beberapa lingkungan pantai dan hingga 350.000 macam limbah plastik per $\mathrm{km}^{2}$ ditemukan di permukaan laut dunia. Saat plastik menjadi partikel berukuran mikro dan nano, memiliki potensi ancaman tambahan pada biota yang hidup di perairan bebas. Ancaman langsung adalah ingesti seperti yang ditemukan pada ikan dan organisme filter feeder yang selain mengancam organisme-organisme tersebut juga memberikan gambaran bahwa sesungguhnya partikel plastik sudah memasuki sistem jejaring makanan/food web.

\section{BAHAN DAN METODE}

Artikel ini merupakan konseptual ide hasil pemikiran yang didasarkan kepada pengamatan di lapangan sepanjang kurun waktu 2016-2019 berdasarkan dokumentasi pribadi. Beberapa artikel ilmiah dan literatur lainnya digunakan sebagai bahan pertimbangan konseptual ide. Tuangan konseptual ide dan analisis disajikan secara deskriptif (Kristina, 2014).

\section{HASIL DAN PEMBAHASAN}

\section{Sumber Dan Distribusi Sampah Plastik Di Sungai Dan Laut}

Menurut NOAA (2013), sampah laut atau marine debris merupakan benda padat yang memiliki sifat persisten, yang diproduksi atau diproses oleh manusia secara langsung atau tidak langsung, dengan sengaja atau tidak sengaja dibuang atau ditinggalkan di dalam lingkungan laut. Sampah laut terdiri berbagai jenis plastik, kain, busa, styrofoam, kaca, keramik, logam, kertas, karet, dan kayu. Beberapa ukuran yang digunakan untuk mengklasifikasikan marine debris, yaitu megadebris $(>100 \mathrm{~mm})$, makrodebris $(>20-100$ $\mathrm{mm})$, mesodebris $(>5-20 \mathrm{~mm})$, dan mikrodebris $(0.3-5$ $\mathrm{mm})$.

Partikel plastik di lingkungan perairan dapat berasal dari:

(1) penghancuran alami sampah-sampah plastik baik oleh aksi mekanis gelombang dan foto-oksidasi dari 
sinar matahari,

(2) pembuangan langsung produk industri (preproduction nurdles),

(3) serabut dari kain sintetik (fleece fabrics),

(4) ban kendaraan mobil dan motor yang aus, serta

(5) peluruhan bahan-bahan yang digunakan dalam produk-produk pembersih/kosmetik.

Masuknya bahan-bahan toksik ini dapat menimbulkan dampak buruk terhadap hewan laut dan diduga kuat melalui proses ingesti dari partikelpartikel renik yang diikuti dengan proses bioakumulasi merunut alur rantai makanan yang lebih tinggi (higher level food chain) yang berarti bahwa biota yang berada pada posisi yang lebih tinggi dalam rantai makanan ini akan lebih terpapar pada konsentrasi bahan toksik yang lebih tinggi. Laporan tentang akumulasi limbah plastik yang melayang-layang di sistem arus lautan (gyres) sangat melimpah. Hal ini semakin meningkatkan kekhawatiran yang kemudian memicu timbulnya kesadaran akan bahaya yang dapat ditimbulkan oleh pencemaran partikel plastik di lautan (Rochman et al., 2014)

\section{Implikasi Sampah Plastik Pada Perairan Dan Ekosistem Dki Jakarta}

Kawasan Pesisisr DKI Jakarta saat ini selain mengalami tekanan lingkungan akibat akumulasi limbah baik limbah industri, limbah domestik, dan limbah lainnya yang bersumber dari darat dan laut juga mengalami tekanan akibat pencemaran sampah plastik. Menurut Hastuti (2014), pada ekosistem mangrove di Pantai Indah Kapuk tercatat plastik tipe makrodebris dominan sekitar $77,7 \%$ dari total makrodebris adalah plastik, diikuti oleh styrofoam $(18,1 \%)$ dan ketebalan makrodebris mencapai $180 \mathrm{~m}$. Selain ekosistem mangrove di Pantai Indah Kapuk, ekosistem mangrove di Suaka Margasatwa Muara Angke mengalami hal yang sama, yaitu terjadi akumulasi sampah sehingga mengganggu pertumbuhan ekosistem mangrove. Kondisi pencemaran sampah di sekitar ekosistem mangrove dan perairan Muara Angke termasuk kategori cukup berat. Terdapat jenis sampah yang cukup berat terutama sampah yang tidak bisa terurai (non-degradable), seperti plastik, styrofoam, sandal/ karet, kaca dan kaleng telah mendominasi kawasan ekosistem mangrove dan perairan di Muara Angke. Kondisi ini dapat menyebabkan aliran pasang surut terganggu oleh adanya tumpukan sampah di sekitar kawasan mangrove, padahal aliran tersebut berperan sangat penting dalam mekanisme aliran nutrisi dan keseimbangan kadar salinitas yang dibutuhkan untuk pertumbuhan mangrove. Gangguan tersebut sepertinya telah terjadi, kondisi pohon mangrove terlihat kurang subur dengan kerapatan yang cukup rendah. Hal ini sejalan dengan hasil simulasi angkutan sampah plastik mikro yang dilakukan oleh Jasmin et al. (2019) bahwa sampah plastik makro yang terangkut dari sungai-

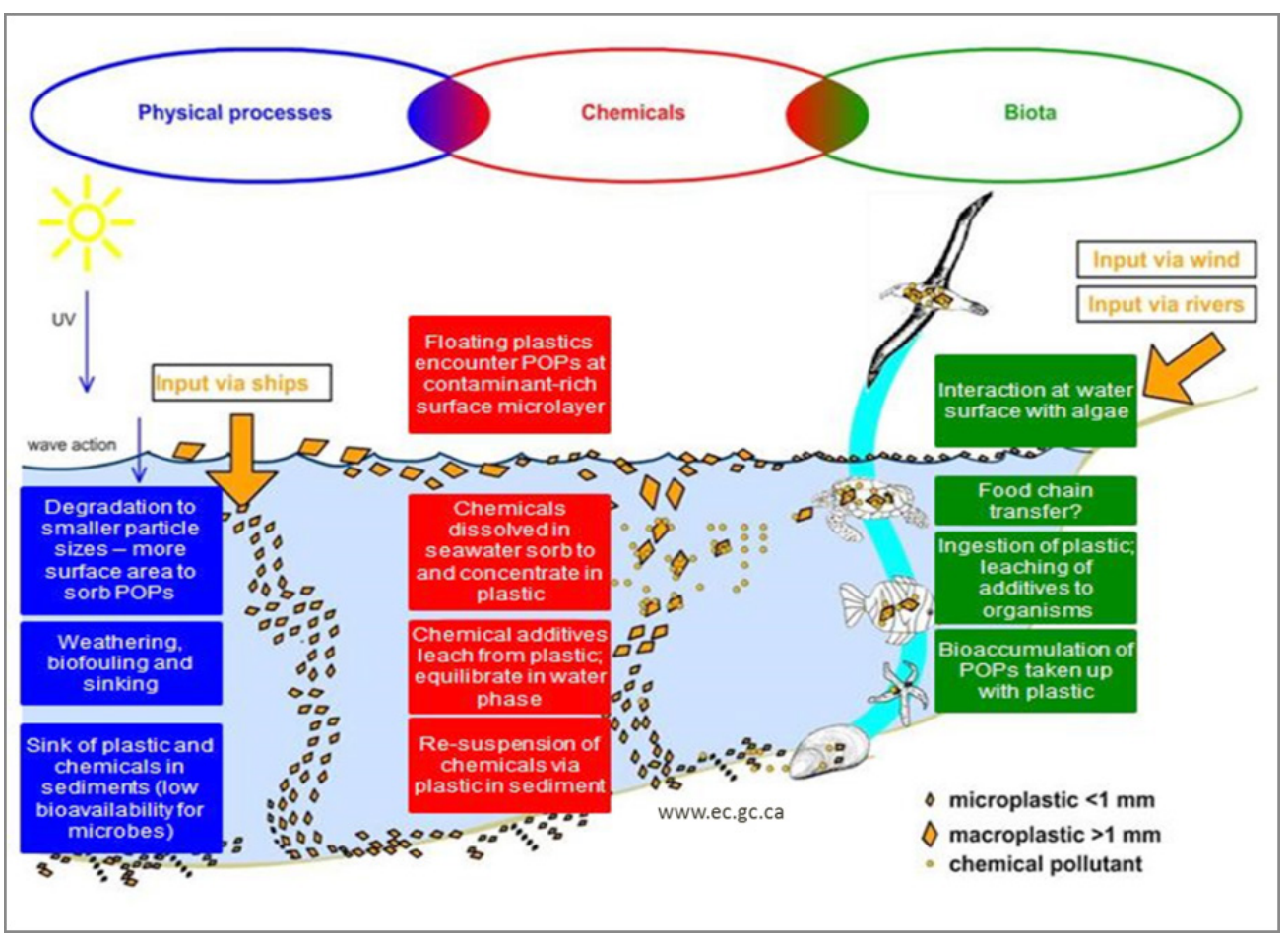

Gambar 2. Nasib Sampah Plastik di Laut (Sumber: www.ec.gc.ca). 

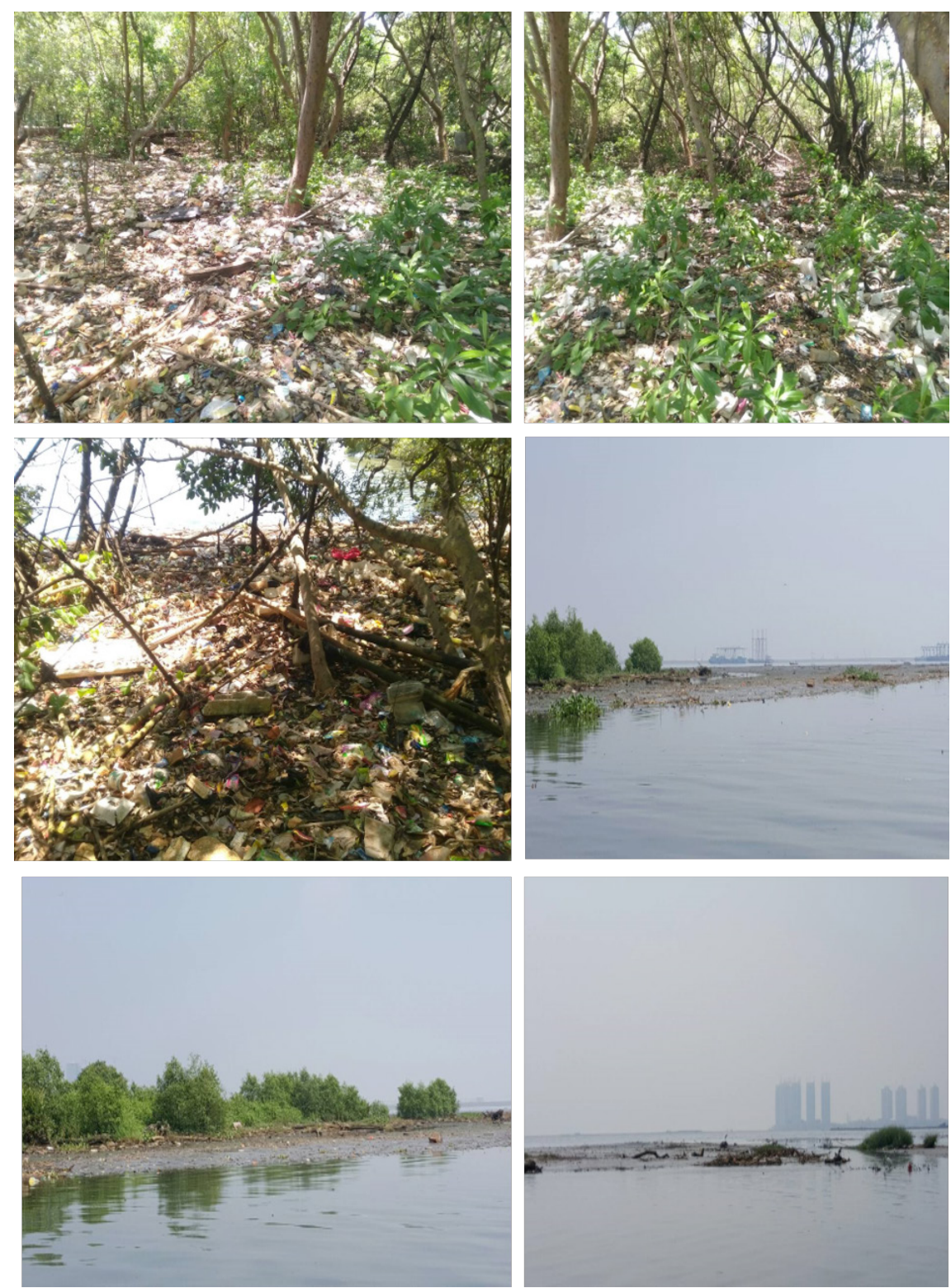

Gambar 3. Kondisi Sampah Pada Perairan dan Ekosistem Mangrove di Pesisir DKI Jakarta (Foto Dokumentasi lapangan 2018-2019).

sungai yang bermuara di Teluk Jakarta, akan terjebak di pesisir utara Jakarta.

Berdasarkan hasil penelitian Abrar \& Ricoh (2005) jumlah sampah di pulau pada Kepulauan Seribu telah mengalami peningkatan. Pada tahun 2005 jumlah sampah di Pulau Pari mencapai 449,4 dan merupakan jumlah tertinggi dibandingkan 7 pulau lainnya yaitu Pulau Untung Jawa, Lancang Besar, Damar Kecil, Ayer, Tidung Kecil, dan Damar Besar. Selain berdampak pada ekosistem mangrove, pencemaran sampah laut ini juga berdampak pada ekosistem terumbu karang di Pulau Pramuka dan sekitarnya. Jenis sampah laut yang paling banyak ditemukan adalah sampah plastik di kedalaman 3m di Pulau Pramuka dan Pulau Panggang.
Terdapat hubungan yang linear antara jumlah sampah dengan tutupan karang terdapat di kedalaman $3 \mathrm{~m}$ di Pulau Pramuka, Pulau Panggang, dan Pulau Air dan 10m di Pulau Pramuka (Assuyuti et al., 2018). Kepulauan Seribu adalah rentan terhadap pasokan sampah plastik baik mikro dan makro dari Selat Karimata dan Laut Jawa, akibat angkutan arus monsun (Handyman et al., 2019). Arus monsun ini bergerak dari barat menuju ke timur pada periode bulan Desember hingga Februari, dan bergerak sebaliknya dari timur ke arah barat saat angina musim timur pada periode Juni hingga Agustus (Siregar et al, 2017).

\section{Menyikapi Hasil Riset Sampah Di Indonesia}

Kawasan Asia Timur, berdasarkan kajian dari 

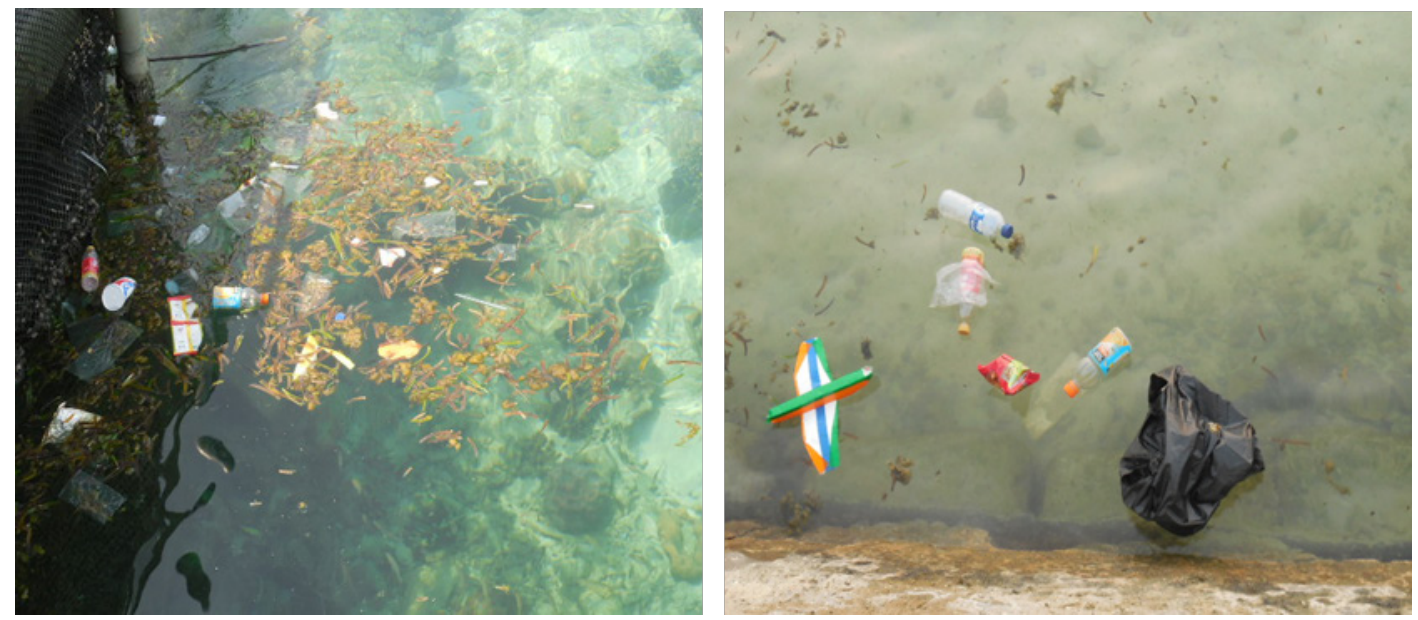

Gambar 4. Kondisi Sampah Pada Perairan Pulau Pramuka (Dokumentasi Lapangan, 2018)
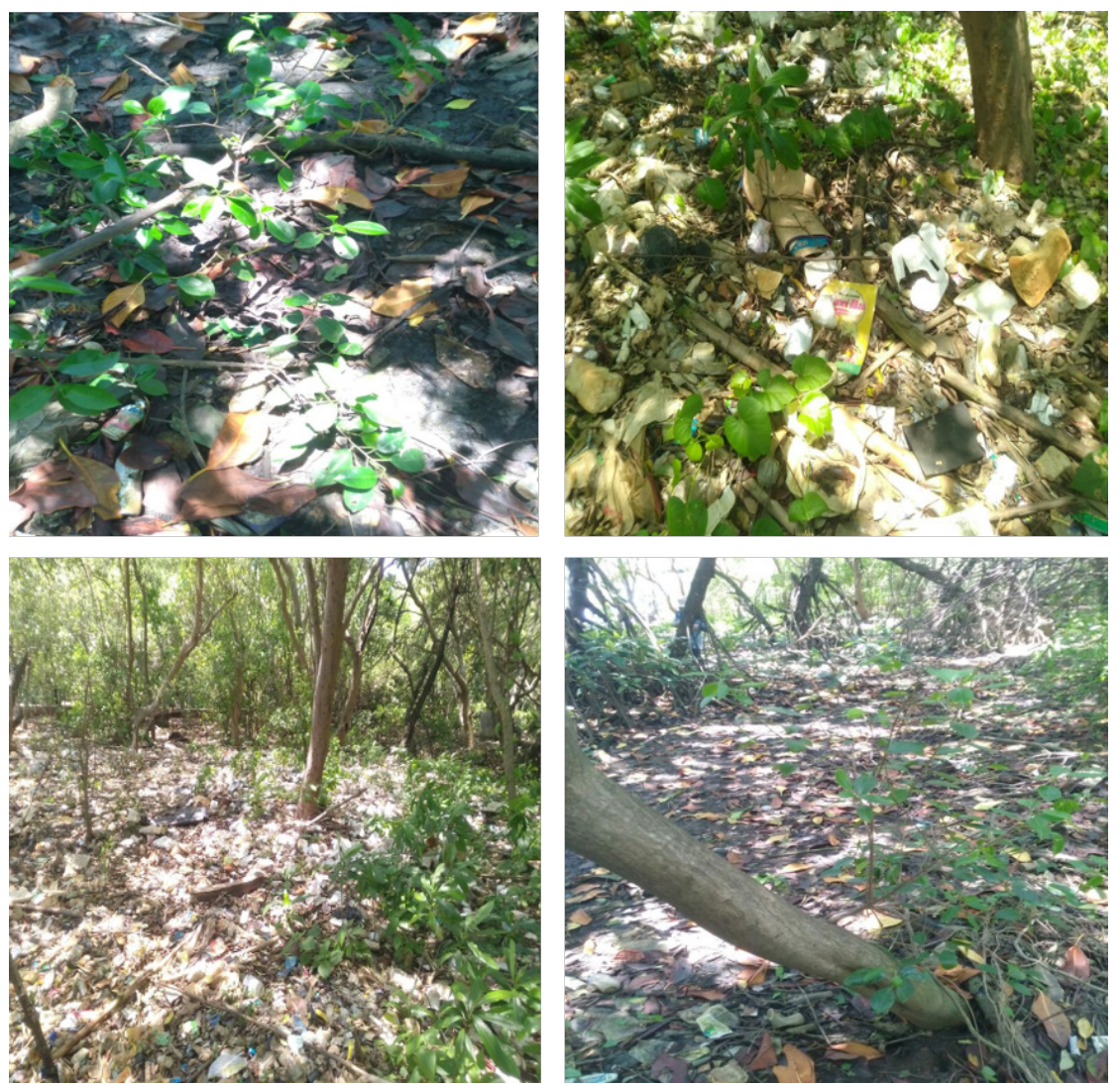

Gambar 5. Kondisi Sampah di Hutan Mangrove di Suaka Margasatwa Muara Angke yang menutupi Permukaan Perairannya (Dokumentasi Lapangan, 2016)

Jambeck et al. (2015) merupakan area paling tinggi, yang menghasilkan sampah plastik ke laut. Indonesia dianggap sebagai penyumbang terbesar kedua untuk sampah plastik di laut antara 0,48-1,29 juta ton/tahun, dengan beberapa perkiraan yang menunjukkan bahwa sampah plastik menyumbang sekitar $10 \%$ dari polusi plastik global. Diketahui bahwa empat sungai di Indonesia termasuk di antara 20 sungai yang paling tercemar di dunia dalam hal sampah plastik. Riset
Jambeck tersebut kemudian dicoba disanggah oleh Purba et al. (2019), yang melakukan review secara umum penelitian sampah plastik di Indonesia yang ternyata telah mulai tumbuh sejak 5-10 tahun ini, walaupun masih bersifat sporadis dan tersebar di penjuru tanah air.

Menurut penelitian University of Georgia faktor pemicu tingginya pencemaran plastik di laut 
di Indonesia sampah plastik yang tidak terkelola di daratan (mismanaged plastic waste) yang mencapai sekitar $83 \%$. Tapi data ini masih harus diverifikasi, karena sampai saat ini Indonesia belum mempunyai data tentang hal tersebut. Upaya meningkatkan pengelolaan sampah terintegrasi dari hulu sampai ke hilir diperlukan untuk mengatasi permasalahan ini. Permasalahan sampah yang menjadi tantangan bagi Indonesia dengan upaya meningkatkan pengelolaan sampah yang secara efektif. Strategi dan rencana jangka pendek, menengah dan panjang termasuk langkahlangkah pengaturan yang dilaksanakan oleh pemerintah diperlukan untuk mengurangi jumlah sampah plastik. Kebijakan nasional mengenai penanganan sampah sebenarnya sudah ada di Indonesia, yaitu Undangundang Nomor 18 Tahun 2008 tentang Pengelolaan Sampah dan Peraturan Pemerintah Nomor 81 Tahun 2012 tentang Pengelolaan Sampah Rumah Tangga dan Sampah Sejenis Sampah Rumah Tangga.

Indonesia juga memiliki peraturan dalam masalah perlindungan laut, yaitu Peraturan Pemerintah Nomor 19 Tahun 1999 tentang Pengendalian Pencemaran dan/atau Perusakan Laut. Pasal 1 butir 2 peraturan pemerintah ini, dijelaskan bahwa pencemaran laut adalah masuknya atau dimasukkannya makhluk hidup, zat, energi, dan/atau komponen lain ke dalam lingkungan laut oleh kegiatan manusia sehingga kualitasnya turun sampai ketingkat tertentu yang menyebabkan lingkungan laut tidak sesuai lagi dengan baku mutu dan/atau fungsinya. Berdasarkan hal tersebut, sampah khususnya sampah plastik termasuk suatu komponen lain yang tidak berasal dari lautan, namun masuk ke lingkungan laut oleh kegiatan manusia, maka dapat dikatakan bahwa sampah plastik rumah tangga merupakan komponen yang dapat mencemari laut.

Peraturan Pemerintah tersebut menjelaskan mengenai pencegahan pencemaran dan kerusakan laut, menjelaskan penanggulangan pencemaran dan/atau kerusakan laut yang dibebankan kepada setiap orang atau penanggung jawab usaha dan/atau kegiatan dan Kepala Instansi yang terkait.

Berdasarkan peraturan-peraturan tersebut Pemerintah sangat serius dalam penanganan sampah plastik di laut. Namun pada kenyataannya, implementasi peraturan-peraturan tersebut masih belum terlihat. Hal ini berkaitan dengan tingkat kesadaran masyarakat dalam penanganan sampah. Saat ini Indonesia masih memerlukan kajian dan analisis lapangan terkait jumlah sampah, terutama sampah plastik di laut, dalam rangka solusi masalah sampah laut di Indonesia untuk mendukung target tujuan Pembangunan Berkelanjutan (TPB) atau Sustainable Development Goals (SDGs) tahun 2030. Selain itu, baseline data sampah laut Indonesia diperlukan untuk mendukung target penurunan $70 \%$ sampah ke laut pada tahun 2025, sesuai Perpres No. 83 tahun 2018 tentang penanganan sampah laut.

\section{KESIMPULAN DAN SARAN}

Saat ini Indonesia masih memerlukan kajian dan analisis lapangan terkait jumlah sampah, terutama sampah plastik di laut, dalam rangka solusi masalah sampah laut di Indonesia untuk mendukung target tujuan Pembangunan Berkelanjutan (TPB) atau Sustainable Development Goals (SDGs) tahun 2030. Selain itu, baseline data sampah laut Indonesia diperlukan untuk mendukung target penurunan $70 \%$ sampah ke laut pada tahun 2025, sesuai Perpres No. 83 tahun 2018 tentang penanganan sampah laut. DKI Jakarta sebagai Ibukota negara, yang memiliki program smart city, dapat berperan penting sebagai panutan bagi kota-kota lain dalam hal pengelolaan sampah kota, maupun sampah di pesisir. Implementasinya pun tidaklah mulai dari nol, terbukti dengan pasukan oranye hingga di Kepulauan Seribu.

\section{UCAPAN TERIMA KASIH}

Dokumentasi dalam tulisan ini adalah bagian dari pelaksanaan kegiatan riset Tanggul Hijau dan SATREPS di Pusat Riset Kelautan Badan Riset dan Sumber Daya Manusia Kementerian Kelautan dan Perikanan . Terima kasih Penulis sampaikan kepada Dr. Widodo S. Pranowo untuk dukungan saran substansi pada tulisan ini.

\section{DAFTAR PUSTAKA}

Abrar, M., \& Ricoh, M. S. (2005). Struktur, Kelimpahan, dan Sebaran Sampah Anorganik di Perairan Kepulauan Seribu, Jakarta, Dampak dan Bentuk Pemanfaatannya.

Assuyuti, Y. M,, Zikrillah, R.B., Tanzil, M.A., Banata, A., \& Utami, P. (2018). Distribusi dan Jenis Sampah Laut serta Hubungannya terhadap Ekosistem Terumbu Karang Pulau Pramuka, Panggang, Air, dan Kotok Besar di Kepulauan Seribu Jakarta, Majalah Ilmiah Biologi Biosfera : A Scientific Journal, 35(2): 91-102, DOI: 
10.20884/1.mib.2018.35.2.707.

Cauwenberghe, L. V., Claessens, M., Vandegehuchte, M. B., Mees, J., \& Janssen, C. R. (2013). Assessment of marine debris on the Belgian Continental Shelf. Marine Pollution Bulletin. 73:161-169.doi:10.1016/j.marpolbul.

Handyman, D. I. W., Purba, N. P., Pranowo, W. S., Harahap, S. A., Dante, I. F., \& Yuliadi, L. P. S. (2019). Microplastics Patch Based on Hydrodynamic Modeling in The North Indramayu, Java Sea. Polish Journal of Environmental Studies, 29(1): 1-8. DOI: $10.15244 /$ pjoes/81704.

Hastuti, A. R. (2014). Distribusi Sampah Laut di Ekosistem Mangrove Pantai Indah Kapuk, Skripsi. IPB.

Jasmin, H. H., Purba, N. P., Harahap, S. A., Pranowo, W. S., Syamsudin, M. L., \& Faizal, I. (2019). The Model of Macro Debris Transport Before Reclamation and in Existing Condition in Jakarta Bay. Jurnal Ilmu \& Teknologi Kelautan Tropis 11(1): 131-140. DOI: http://dx.doi.org/10.29244/ jitkt.v11i1.24777.

Kementerian Perindustrian. (2013). Berita Industri: Semester I, Konsumsi Plastik 1,9 Juta Ton. http:// www.kemenperin.go.id/artikel/6262/SemesterI,-Konsumsi-Plastik-1,9-Juta-Ton [diakses 01 Agustus 2019]

Kristina, H. J. (2014). Model konseptual untuk mengukuradaptibilitas bank sampah di Indonesia.J@TI Undip, 9(1): 19-28.

[NOAA] National Oceanic and Atmospheric Administration. (2013). Programmatic Environmental Assessment (PEA) for the NOAA Marine Debris Program (MDP). Maryland (US): NOAA. $168 \mathrm{p}$.

Purba, N. P., Handyman, D. I. W., Pribadi, T. D., Syakti, A. D., Pranowo, W.S., Harvey, A., \& Ihsan, Y.N. (2019). Marine debris in Indonesia: A review of research and status (Review). Marine Pollution Bulletin 146, September 2019, Pages 134-144. https://doi.org/10.1016/j. marpolbul.2019.05.057.
Shah, A. A., Hasan, F., Hameed, A., \& Ahmed, S. (2008). Biological degradation of plastics: a comprehensive review. Biotechnol. Adv. 26, $246 \mathrm{e} 265$.

Siregar, S. N., Sari, L. P., Purba, N. P.. Pranowo, W. S., \& Syamsuddin. M. L. (2017). Pertukaran massa air di Laut Jawa terhadap periodisitas monsun dan Arlindo pada tahun 2015. J. Depik 6(1): 4459. DOI: 10.13170/depik.6.1.5523.

Sahwan, F. L. (2011). Sistem Pengelolaan Limbah Plastik di Indonesia. Jurnal Teknologi Lingkungan, 6(1). 
